Edu Consilium: Jurnal BK Pendidikan Islam

Vol.2, No.2, 2021, hlm.xx-xxx

DOI: $10.1905 /$ ec.v1i1.1808

ISSN 2503-3417 (online)

ISSN 2548-4311 (cetak)

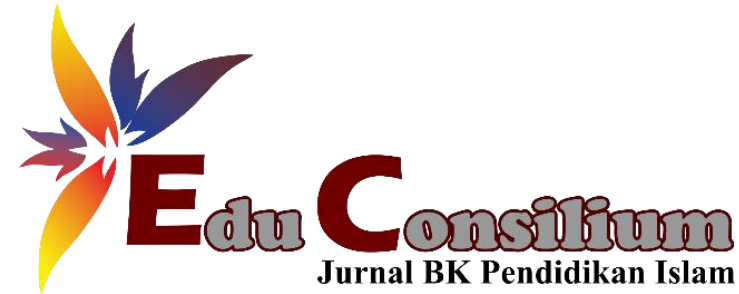

\title{
HUBUNGAN ANTARA SELF EFFICACY DENGAN PENGAMBILAN KEPUTUSAN KARIER PADA SISWA KELAS XII PUTRI MA MIFTAHUL QULUB GALIS PAMEKASAN
}

\section{Nuri Istiqlailia ${ }^{1 *}$, Ishlakhatus Sa'idah ${ }^{2}$}

1,2 Program Studi Bimbingan dan Konseling Pendidikan Islam, Fakultas Tarbiyah, Intitut Agama Islam Negeri Madura, Jalan Panglegur Km 4, Pamekasan, Jawa Timur, 693271, Indonesia

*e-mail : istiqlailia29@gmail.com 


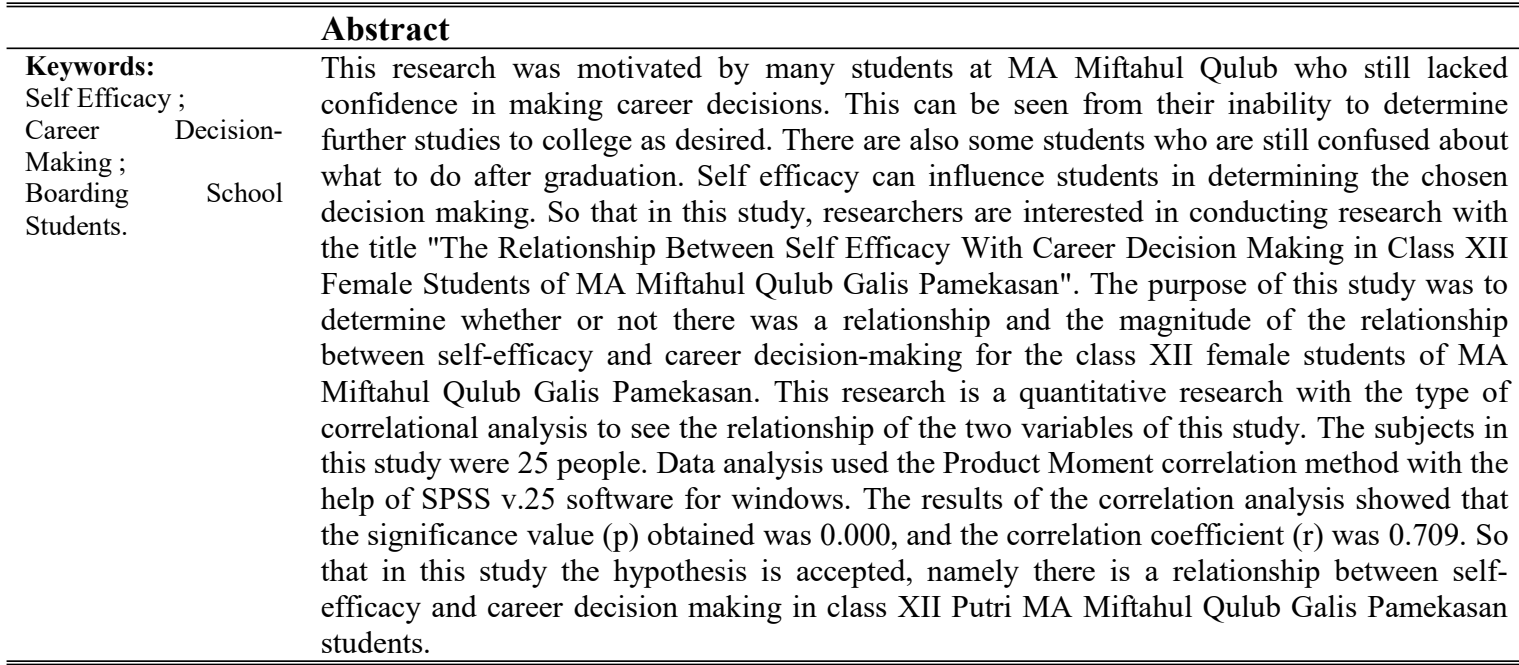

\begin{tabular}{ll}
\hline \hline & Abstrak: \\
\hline Kata Kunci: & Penelitian ini dilatarbelakangi oleh banyak siswa di MA Miftahul Qulub yang masih \\
Efikasi Diri; & kurang percaya diri dalam pengambilan keputusan kariernya. Hal ini dilihat dari \\
Pengambilan & ketidakmampuan mereka dalam penentuan studi lanjutan ke perguruan tinggi sesuai \\
Keputusan Karier; & yang diinginkan. Beberapa siswa juga ada yang masih kebingungan tentang apa yang \\
Siswa MA. & akan dilakukan setelah lulus. Self efficacy dapat mempengaruhi siswa dalam \\
& menentukan pengambilan keputusan yang dipilih. Sehingga dalam penelitian ini, \\
& peneliti tertarik melakukan penelitian dengan judul "Hubungan Antara Self Efficacy \\
& dengan Pengambilan Keputusan Karier Pada Siswa Kelas XII Putri MA Miftahul \\
& Qulub Galis Pamekasan". Tujuan penelitian ini untuk mengetahui ada tidaknya \\
& hubungan dan besaran hubungan antara self efficacy dengan pengambilan keputusan \\
& karier siswa kelas XII putri MA Miftahul Qulub Galis Pamekasan. Penelitian ini \\
& merupakan penelitian kuantitatif dengan jenis analisis korelasional untuk melihat \\
& hubungan dari kedua variabel dari penelitian ini. Subjek dalam penelitian ini \\
& sebanyak 25 orang. Analisis data menggunakan metode korelasi Product Moment \\
& dengan bantuan software SPSS v.25 for windows. Hasil analisis korelasi \\
& menunjukkan nilai signifikansi $(p)$ yang diperoleh sebesar 0,000, dan nilai koefisien \\
& korelasi (r) sebesar 0,709. Sehingga dalam penelitian ini Hipotesis diterima yaitu \\
& terdapat hubungan antara self efficacy dengan pengambilan keputusan karier pada \\
siswa kelas XII Putri MA Miftahul Qulub Galis Pamekasan.
\end{tabular}

\section{PENDAHULUAN}

Siswa pada jenjang Sekolah Menengah Atas (SMA) merupakan siswa yang usianya berkisar pada rentang 13-19 tahun. Dalam rentang usia ini individu tergolong ke dalam usia masa remaja. Proses peralihan di usia remaja menyangkut psikologis maupun pertumbuhan fisik yang berkembang dengan pesat. Di samping itu, siswa pada usia remaja harus mempunyai kesiapan dan dituntut untuk memenuhi harapan sebagai orang dewasa dengan tugas-tugas perkembangan yang dimilikinya.

Di sisi lain, penetapan identitas diri remaja harus sudah terfikirkan ingin menjadi apa pada masa yang akan datang. Remaja dikatakan berhasil dalam menentukan pandangan di masa depan jika sudah mengerti dan memahami persamaan serta perbedaan dirinya dengan orang lain, kemudian menyadari kelebihan dan kekurangan dirinya, selain itu pemikirannya menjadi semakin abstrak, logis, dan idealis sehingga dapat mengerti dan memahami arah masa depan atau karier yang akan dipilihnya. 
Pandangan karier atau masa depan merupakan salah satu bentuk perkembangan kognitif yang terjadi pada masa remaja. Berdasarkan Kamus Besar Bahasa Indonesia, karier adalah perkembangan dan kemajuan dalam kehidupan, pekerjaan, jabatan, dan sebagainya (KBBI, 2003). Menurut Farlex, karier adalah the general progression of your working or professional life (Hartono, 2016). Dengan demikian, karir merupakan salah satu fenomena berupa aktivitas profesional yang berhubungan dengan kemajuan dalam bidang pekerjaan atau pendidikan seseorang dalam hidupnya.

Dalam era globalisasi saat ini, kita dituntut untuk memiliki kesiapan yang matang dalam berbagai hal baik dalam dunia kerja ataupun dalam dunia pendidikan. Seiring dengan berkembangnya teknologi, menghadirkan kesempatan-kesempatan baru dalam kehidupan untuk mengembangkan potensi diri dengan berbagai pilihan karier untuk menuju masa depan yang lebih baik. Pengambilan keputusan karier yang baik, dapat menunjang perkembangan potensi diri secara maksimal meskipun ada faktor lain yang kurang mendukung sehingga dapat menguntungkan bagi kehidupan seseorang (Apriansyah, 2018).

Proses pengambilan keputusan karier tersebut diperlukan pemikiran yang realistis dan dalam waktu yang panjang. Hal ini dikarenakan keputusan karier yang dipilih merupakan tanggung jawab yang harus diemban selama hidupnya. Oleh karena itu, suatu tahapan yang penting bagi seseorang remaja adalah pengambilan keputusan karir yang tepat. Pengambilan keputusan karier merupakan hasil dari rangkaian pengalaman belajar yang dijalani oleh seseorang mulai dari tingkat dasar sampai lanjutan. Seperti keputusan tentang jenis pekerjaan yang didambakan seseorang berkaitan erat dengan pendidikan yang harus diselesaikan untuk mempersiapkan dirinya memasuki dunia kerja.

Pengambilan keputusan karier bagi siswa menengah atas ialah dengan memilih studi lanjutan yang akan ditempuh atau memutuskan untuk bekerja. Hal ini sangat penting karena akan menjadi penentuan karier siswa di masa depan. Dalam pemilihan keputusan karier secara optimal, hal itu akan dipengaruhi oleh faktor internal maupun faktor eksternal. Faktor dari dalam individu tentunya sangat memengaruhi pengambilan keputusan karier yang baik, seperti salah satu factor yaitu self efficacy yang tinggi.

Bandura menyebutkan bahwa kemampuan yang dimiliki seseorang dalam melaksanakan suatu tugas akan berkaitan dengan self efficacy yang berfungsi sebagai prediktor kuat dari perilaku. Salah satu faktor motivasi yang dapat menambah atau mengurangi tindakan terhadap kemampuan individu untuk mengatasi suatu peristiwa yang mempengaruhi kehidupannya merupakan self efficacy (Susanto, 2018). Sedangkan menurut Baron dan Byrne self efficacy adalah penilaian seseorang terhadap kompetensi diri serta kemampuan dalam mencapai tujuan, melaksanakan suatu tugas, dan mengatasi hambatan (Ghufron, 2014).

Berdasarkan hal di atas, dapat disimpulkan bahwa self efficacy adalah keyakinan individu terhadap kemampuan yang dimiliki untuk mengatur dan melakukan serangkaian tindakan untuk bertahan dalam menghadapi segala tantangan untuk mencapai tujuan yang diinginkan. Dengan 
demikian, dapat dimengerti bahwa siswa yang mempunyai self efficacy tinggi dapat membantu siswa dalam menentukan besar usaha yang akan dilakukan dalam suatu kegiatan dan dapat memperkirakan seberapa jauh akan menghadapi hambatan dan juga rintangan dalam setiap situasi. Dalam pemilihan karier tentunya harus dipikirkan dan dipertimbangkan secara matang, dikarenakan akan berpengaruh untuk keberlangsungan hidup dalam kurun waktu yang cukup lama.

Proses pengambilan keputusan karir sangat dipengaruhi oleh self efficacy, hal ini dapat diketahui dari empat sumber penting, diantaranya: 1) Pengalaman akan kesuksesan berpengaruh sangat besar terhadap self efficacy, hal ini menjadi dasar pada pengalaman otentik (pengalaman yang nyata); 2) Pengalaman individu lain yaitu dengan mengamati setiap pengalaman orang lain baik pengalaman orang sukses maupun pengalaman orang yang gagal; 3) Persuasi verbal yaitu digunakan dalam keyakinan individu untuk mempunyai kemampuan meraih apa yang di cita-citakan; 4) Keadaan fisiologis adalah suatu keadaan secara emosional maupun fisik dalam individu yang dapat mempengaruhi self efficacy dalam memilih karier (Kurniawati, 2018).

Rencana karier seharusnya memang sudah direncanakan sejak dini karena dengan memilih Sekolah Menengah Atas (SMA), Sekolah Menengah Kejuruan (SMK) ataupun Madrasah Aliyah (MA) tentunya sudah menentukan karier mana yang akan dituju dengan jurusan yang telah dipilih saat ini. Namun, dewasa ini penentuan karier siswa tidak sejalan dengan kenyataan. Kebanyakan siswa masuk ke sekolah bukan karena sudah menentukan pilihan kariernya, namun karena pilihan orang tua, terpengaruh teman atau bahkan memilih sekolah karena sekolah tersebut favorit (Sa'idah, dkk., 2021). Kebanyakan siswa percaya jika bersekolah di sekolah favorit maka dia akan sukses seperti alumni sekolah tersebut. Realitanya, kebanyakan siswa sampai saat ini belum tahu tentang apa yang akan dilakukan ketika sudah lulus. Jika ingin kuliah akan mengambil jurusan apa dan dimana, dan jika ingin bekerja akan bekerja sebagai apa dan bagian apa. Tentunya hal inilah kenapa self efficacy sangat diperlukan oleh siswa SMA dan sederajat tentunya dalam pemilihan karier.

Madrasah Aliyah Miftahul Qulub merupakan satu dari sekolah swasta yang terdapat di Kabupaten Pamekasan dengan berbasis pondok pesantren. Berdasarkan observasi peneliti, kebanyakan siswa di MA Miftahul Qulub masih kurang percaya diri untuk meneruskan studi lanjutan ke perguruan tinggi yang di inginkan. Beberapa siswa juga ada yang masih kebingungan tentang apa yang akan dilakukan setelah lulus. Pemetaan kelas di sekolah ini berbasis pondok pesantren yang menggunakan sistem pisah antara siswa putra dan putri menjadi tantangan tersediri. Oleh karena itu, peneliti membuat batasan dalam penelitian ini yang hanya fokus pada siswa putri. Selain itu, batasan selanjutnya adalah memprioritaskan siswa kelas XII karena peneliti ingin mengetahui sejauh mana self efficacy mereka dalam pengambilan keputusan karier.

Dengan sedikit penjelasan tentang self efficacy dan adanya fenomena tersebut, maka peneliti memutuskan untuk melaksanakan penelitian dengan judul "Hubungan Antara Self Efficacy Dengan Pengambilan Keputusan Karier Pada Siswa Kelas XII Putri MA Miftahul Qulub Galis Pamekasan”. 
Adapun tujuan dalam penelitian ini yaitu: 1) Untuk mengetahui ada tidaknya hubungan antara self efficacy dengan pengambilan keputusan karier siswa kelas XII putri MA Miftahul Qulub Galis Pamekasan. 2) Untuk mengetahui besaran hubungan antara self efficacy dengan pengambilan keputusan karier siswa kelas XII putri MA Miftahul Qulub Galis Pamekasan.

\section{METODE}

Penelitian ini merupakan jenis penelitian yang menggunakan pendekatan kuantitatif dengan jenis analisis korelasional untuk melihat hubungan dari kedua variabel dari penelitian ini. Subjek dalam penelitian ini sebanyak 25 orang dari kelas XII IPA 2 yang dipilih berdasarkan purposive sampling (sampel bertujuan). Adapun rumus yang digunakan dalam penelitian ini untuk melihat adanya hubungan antara self efficacy dengan pengambilan keputusan karier siswa yaitu:

$$
{ }^{\mathrm{r}} \mathrm{xy}=\frac{\sum \mathrm{xy}}{\sqrt{\left(\sum \mathrm{x} 2\right)(\Sigma \mathrm{y} 2)}}
$$

Keterangan:

$$
\begin{aligned}
{ }^{\mathrm{r}} \mathrm{xy} & =\text { koefisien korelasi product moment } \\
\sum \mathrm{xy} & =\text { jumlah dari hasil kali } \mathrm{x} \text { dan } \mathrm{y} \\
\sum \mathrm{x}^{2} & =\text { jumlah skor } \mathrm{x} \text { yang dikuadratkan } \\
\sum \mathrm{y}^{2} & =\text { jumlah skor } \mathrm{y} \text { yang dikuadratkan }
\end{aligned}
$$

Guna memberikan makna terhadap hasil penelitian, maka peneliti menggunakan pedoman sebagai berikut:

1. Hipotesis diterima apabila $r$ hitung lebih besar dari nilai $r$ tabel product moment baik signifikasi $5 \%$, kemudian hipotesis ditolak jika $\mathrm{r}$ hitung lebih kecil dari nilai $\mathrm{r}$ tabel product moment dengan signifikasi 5\%.

2. Guna mengetahui besarnya hubungan antara variabel $\mathrm{X}$ (pengaruh self efficacy) dengan variabel Y (pengambilan keputusan karir).

Analisis data menggunakan teknik korelasi Product Moment dengan bantuan software SPSS v.25 for windows. Untuk mengetahui tingkat hubungan antara self efficacy dengan pengambilan keputusan karier, dapat dilihat dari nilai koefisien korelasi. Besarnya koefisien korelasi yang dikemukakan oleh Sugiyono (2018), menjadi dasar untuk mengetahui interpretasi dari tingkat kekuatan hubungan, yaitu sebagai berikut:

Tabel 1. Pedoman Interprestasi Koefisien Korelasi

\begin{tabular}{|c|c|}
\hline Interval Koefisien & Tingkat Hubungan \\
\hline $0,00-0,199$ & Sangat rendah \\
$0,20-0,339$ & Rendah \\
\hline
\end{tabular}




\begin{tabular}{|c|c|}
\hline $0,40-0,559$ & Cukup \\
$0,60-0,779$ & Kuat \\
$0,80-1,000$ & Sangat Kuat \\
\hline
\end{tabular}

\section{HASIL}

Hasil penelitian ini diperoleh dari angket penelitian yang disebarkan kepada siswa dengan bimbingan dari peneliti dalam pengisiannya. Hal ini bertujuan agar angket yang disebar mampu diisi oleh siswa dengan baik dan benar. Dari penyebaran angket yang sudah dilakukan pada subjek penelitian, maka diperoleh hasil yang dapat dilihat dari tabel 2 berikut ini:

Tabel 2. Perolehan Total Skor Variabel X (Self Efficacy) dan

Skor Variabel Y (Pengambilan Keputusan Karier)

\begin{tabular}{|c|c|c|}
\hline \multirow{2}{*}{ SUBJEK } & SELF EFFICACY & $\begin{array}{c}\text { PENGAMBILAN } \\
\text { KEPUTUSAN KARIER }\end{array}$ \\
\hline & TOTAL & TOTAL \\
\hline 1 & 39 & 77 \\
\hline 2 & 40 & 86 \\
\hline 3 & 36 & 76 \\
\hline 4 & 39 & 70 \\
\hline 5 & 40 & 81 \\
\hline 6 & 40 & 73 \\
\hline 7 & 43 & 81 \\
\hline 8 & 41 & 65 \\
\hline 9 & 39 & 88 \\
\hline 10 & 43 & 84 \\
\hline 11 & 42 & 90 \\
\hline 12 & 34 & 74 \\
\hline 13 & 46 & 97 \\
\hline 14 & 36 & 65 \\
\hline 15 & 37 & 91 \\
\hline 16 & 44 & 89 \\
\hline 17 & 43 & 92 \\
\hline 18 & 34 & 64 \\
\hline 19 & 35 & 77 \\
\hline 20 & 38 & 74 \\
\hline 21 & 45 & 87 \\
\hline
\end{tabular}




\begin{tabular}{|c|c|c|}
\hline 22 & $\mathbf{3 6}$ & $\mathbf{8 0}$ \\
\hline 23 & $\mathbf{5 3}$ & $\mathbf{1 0 0}$ \\
\hline 24 & $\mathbf{3 7}$ & $\mathbf{7 6}$ \\
\hline 25 & $\mathbf{3 5}$ & $\mathbf{7 4}$ \\
\hline
\end{tabular}

Hasil penelitian angkat di atas selanjutnya melalui tahapan uji normalitas yang bertujuan untuk mengetahui data tersebut normal atau tidak. Setelah dihitung menggunakan bantuan software SPSS v.25 for windows, didapatkan nilai signifikansi Shapiro-Wilk yaitu pada variable self efficacy sebesar 0,068 dan variable pengambilan keputusan karier sebesar 0,682. Angka sig. Shapiro-Wilk tersebut lebih tinggi dibandingkan dengan taraf signifikansi $5 \%(0,05)$ atau sig. $>0,05$. Hal ini memberikan gambaran bahwa data kedua variable berdistribusi normal.

Uji linearitas diperlukan untuk mengetahui hubungan dua variabel bersifat linear atau tidak secara signifikan. Setelah dihitung menggunakan bantuan software SPSS v.25 for windows, diperoleh nilai Deviation from Linearity Sig. adalah 0,624 lebih besar dari 0,05. Maka dapat ditarik kesimpulan yakni variabel X (self efficacy) dan variabel Y (pengambilan keputusan karir) memiliki hubungan linear secara signifikan. Sedangkan nilai $F$ dari output, diperoleh $F_{\text {hitung }}$ adalah $0,831<\mathrm{F}_{\text {tabel }} 4,279$. Karena nilai $\mathrm{F}_{\text {hitung }}$ lebih kecil dari nilai $\mathrm{F}_{\text {tabel }}$ maka variabel $\mathrm{X}$ (self efficacy) dan variabel $\mathrm{Y}$ (pengambilan keputusan karier) memiliki hubungan linear secara signifikan.

Setelah mengetahui data penelitian normal dan linear, maka data tersebut dianalisis menggunakan korelasi product moment untuk menguji hipotesis yang telah diajukan oleh peneliti. Berikut adalah hasil dari uji hipotesis menggunakan software SPSS v.25 for windows:

Tabel 3. Hasil Uji Hipotesis Variabel Self Efficacy dan Pengambilan Keputusan Karier Correlations

\begin{tabular}{|c|c|c|c|}
\hline & & Self Efficacy & $\begin{array}{c}\text { Pengambilan } \\
\text { Keputusan Karier }\end{array}$ \\
\hline \multirow[t]{3}{*}{ Self Efficacy } & $\begin{array}{l}\text { Pearson } \\
\text { Correlation }\end{array}$ & 1 & $.709^{* *}$ \\
\hline & Sig. (2-tailed) & & .000 \\
\hline & $\mathrm{N}$ & 25 & 25 \\
\hline \multirow[t]{3}{*}{$\begin{array}{l}\text { Pengambilan } \\
\text { Keputusan Karier }\end{array}$} & $\begin{array}{l}\text { Pearson } \\
\text { Correlation }\end{array}$ & $.709^{* *}$ & 1 \\
\hline & Sig. (2-tailed) & .000 & \\
\hline & $\mathrm{N}$ & 25 & 25 \\
\hline
\end{tabular}

**. Correlation is significant at the 0.01 level (2-tailed).

Pengujian hipotesis dari penelitian ini menggunakan korelasi product moment, analisis data dengan menggunakan aplikasi software SPSS v.25 for windows. Setelah dilakukan uji hipotesis, diperoleh hasil nilai koefisien korelasi $(r)$ sebesar 0,709 dengan taraf signifikansi $(p)$ yang diperoleh 
sebesar 0,000. Dengan taraf signifikansi 0,05 (5\%), maka dapat di peroleh harga $r_{\text {tabel }}$ sebesar 0,396. Dari data di atas diketahui harga $r$ hitung 0,709, dapat disimpulkan bahwa nilai $r$ hitung lebih besar dari pada $r$ tabel $(0,709>0,396)$, sehingga Ha diterima dan Ho ditolak. Artinya hasil tersebut mengindikasikan bahwa terdapat hubungan yang bersifat positif, dan kuat antara self efficacy dengan pengambilan keputusan karier pada siswi kelas XII putri MA Miftahul Qulub Galis.

\section{PEMBAHASAN}

Self efficacy atau dalam bahasa indonesia efikasi diri merupakan sikap yakin seseorang terhadap kemampuan dirinya untuk menunjukkan performa tertentu yang dapat memengaruhi kehidupannya. Menurut Bandura self efficacy ialah keyakinan yang terdapat dalam diri seseorang akan memampuannya dalam melakukan suatu kontrol terhadap dirinya sendiri dan kejadian di sekitarnya. Self efficacy juga digambarkan sebagai karakteristik seseorang dalam merasakan, berfikir, memotivasi diri, dan bertindak (Feits \& Feist, 2010).

Self efficacy adalah pengetahuan tentang diri seseorang yang paling mempengaruhi dalam kehidupan setiap harinya. Hal tersebut dikarenakan self efficacy berpengaruh terhadap individu dalam bertindak untuk meraih tujuan yang didalamnya meliputi memperkirakan kejadian-kejadian yang akan dilalui, contohnya pengambilan keputusan karier seseorang. Self efficacy mampu menumbuhkan sikap keyakinan individu ketika dihadapkan pada pemilihan karier sehingga ia berusaha untuk melakukan langkah-langkah yang tepat guna mencapai pengambilan keputusan karier (Isnain, 2018).

Pengambilan keputusan karir ialah proses dinamis dan berkelanjutan, di mana aspek pemahaman diri (self knowledge) seperti nilai-nilai dan sikap, kemampuan, kepribadian, minat karir, dan aspek pemahaman karier seperti macam karir dan pendidikan karier sebagai hal penting yang ikut berperan (Hartono, 2016). Ketika akan melakukan pengambilan keputusan karier siswa mulai belajar merencanakan karier dan menentukan pilihan kelanjutan studi sesuai dengan tujuan karier yang ingin dicapai. Kesesuaian keputusan karier yang dibuat berdasarkan kemampuan yang dimiliki akan mempermudah siswa dalam meraih kesuksesan dimasa depan, sedangkan ketidaksesuaian pengambilan keputusan karier dapat menghambat siswa dalam meraih keberhasilan dimasa depan (Setiobudi, 2017).

Pengambilan keputusan karir merupakan aspek yang penting untuk penentuan arah yang akan dicapai demi masa depan. Selain itu pentingnya pengambilan keputusan karier juga akan berpengaruh terhadap pekerjaan yang akan ditekuni. Sehingga hubungan antara self efficacy dan pengambilan keputusan karir harus diketahui agar siswa bisa mengarahkan dirinya untuk menentukan pilihan karier yang tepat. Penelitian dilakukan pada kelas XII IPA 2 Putri di MA Miftahul Qulub, kelas di Madrasah Aliyah Miftahul Qulub dipisah antara siswa putra dan putri, dikarenakan MA Miftahul Qulub berbasis pondok pesantren. Hal ini menjadi pertimbangan peneliti untuk memfokuskan penelitian di siswa putri. Dengan alasan, siswa putri lebih rajin dan lebih bisa diajak komunikasi. Selain itu, untuk kelas 
XII lebih diutamakan karena peneliti ingin mengetahui sejauh mana self efficacy mereka dalam pengambilan keputusan karier.

Pada penelitian di sekolah MA Miftahul Qulub, self efficacy dengan pengambilan keputusan karier saling berhubungan. Hasil uji hipotesis dengan analisis korelasi product moment menggunakan bantuan software SPSS v.25 for windows menunjukkan bahwa terdapat hubungan yang kuat antara self efficacy dengan pengambilan keputusan karir. Hal itu ditunjukkan dengan nilai signifikansi $(p)$ yang diperoleh sebesar 0,000 dan nilai koefisien korelasi $(r)$ sebesar 0,709 yang menunjukkan bahwa hipotesis alternatif $\left(\mathrm{H}_{\mathrm{a}}\right)$ diterima yaitu self effcacy dengan pengambilan keputusan karir pada siswa kelas XII putri di MA Miftahul Qulub memiliki hubungan yang positif. Dimana meningkatnya self efficacy maka meningkatkan pula pengambilan keputusan karir siswa, begitu pula sebaliknya.

Dari hipotesis tersebut dapat disimpulkan bahwa siswa kelas XII putri MA Miftahul Qulub sudah mempunyai kenyakinan dalam dirinya terhadap karier yang akan diambil setelah lulus. Hal ini dibuktikan dengan terdapat hubungan positif antara self efficacy dengan pengambilan keputusan karir siswa tersebut. Pengambilan keputusan karier yang benar harus didukung dengan self efficacy yang tinggi. Hal itu tentunya ditunjang dengan persiapan diri untuk menghadapi berbagai rintangan yang akan ditemui saat ingin mencapai tujuan karier yang diinginkan.

Individu yang mencoba melaksanakan suatu hal, berharap kepada hasil percobaan tersebut dan bertindak dengan cara-cara yang dianjurkan untuk pencapaian tujuannya. Individu tersebut adalah individu yang memiliki keyakinan terhadap abilitas dirinya dalam pengambilan keputusan karir dimasa depan (Sa'idah, dkk., 2021). Siswa membutuhkan self efficacy sebagai keyakinan terhadap kemampuannya dalam mengelola keinginannya untuk berhasil. Saat seseorang memiliki self efficacy maka siswa itu akan memahami lebih dalam mengenai kebutuhan dan tindakan apa yang harus diambilnya untuk mencapai cita-citanya (Fadhila, 2017).

Dari penjelasan tersebut pada dasarnya self efficacy merupakan dasar utama dari suatu tindakan. Seorang murid yang mempunyai self efficacy dan pengambilan keputusan karir yang sangat baik, maka siswa tersebut akan memiliki usaha yang tinggi dalam mengerjakan tugas yang berikan oleh gurunya dengan sungguh-sungguh. Karena self efficacy tersebut didasarkan pada keyakinan siswa terhadap kemampuan yang dimiliki oleh dirinya sendiri.

\section{SIMPULAN}

Berdasarkan hasil dari analisis data yang telah dilakukan di sekolah MA Miftahul Qulub dapat diketahui bahwa berdasarkan hasil uji hipotesis menggunakan analisis korelasi product moment dengan menggunakan bantuan software SPSS v.25 for windows menunjukkan terdapat hubungan antara self efficacy dengan pengambilan keputusan karier.Hal itu ditunjukkan dengan nilai signifikansi ( $p$ ) yang diperoleh sebesar 0,000, dan nilai koefisien korelasi $(r)$ sebesar 0,709 yang menunjukkan bahwa hipotesis diterima yaitu terdapat hubungan yang positif antara self efficacy dengan 
pengambilan keputusan karier pada siswa kelas XII putri di MA Miftahul Qulub. Sehingga semakin tinggi self efficacy maka semakin tinggi pula pengambilan keputusan karier siswa, bagitu pula sebaliknya.

\section{DAFTAR RUJUKAN}

Apriansyah, Agus dkk. (2018). Hubungan Antara Efikasi Diri Dengan Kemampuan Pengambilan Keputusan Karir Siswa MAN 2 Kota Bengkulu, Jurnal Ilmiah Bimbingan dan Konseling FKIP Universitas Bengkulu, Volume 01 (03).

Fadhila, Dika dkk. (2017). Pengaruh Efikasi Diri Terhadap Kematangan Karir Siswa SMAN Banda Aceh, Jurnal Ilmiah Mahasiswa Bimbingan dan Konseling, Volume 02 (03).

Feits, Jess Feist \& Gregory J. (2010). Teori Kepribadian.Jakarta: Penerbit Salemba Humanika.

Ghufron, M. Nur dkk. (2014). Teori-Teori Psikologi.Jogjakarta: Ar-Ruzz Media

Hartono. (2016). Bimbingan Karier. Jakarta: Kencana.

Hurlock, Elisabet B. (2018). Psikologi Perkembangan: Suatu Pendekatan Sepanjang Rentang Kehidupan (Edisi 5). Jakarta: Erlangga.

Isnain, Mauliddian. (2018).Hubungan Antara Efikasi Diri Dengan Kematangan Karir Pada Siswa Kelas XI Di SMKN 1 Surabaya, Jurnal Penelitian Psikologi, Volume 05 (02)

Kurniawati, Yuraida Ita dkk. (2018). Pentingnya Layanan Informasi Karier dan Efikasi Diri dalam Pengambilan Keputusan Studi Lanjut Siswa.Sukoharjo: CV Sindunata.

Saidah, I., Atmoko, A., \& Muslihati, M. (2021). Aspirasi Karier Generasi Milenial. Edu Consilium: Jurnal Bimbingan dan Konseling Pendidikan Islam, 2(1), 62-89.

Santrock, John W. (2008). Psikologi Pendidikan (Edisi Kedua), Jakarta: Kencana.

Setiobudi, Jodi. (2017). Pengaruh Efikasi Diri Terhadap Pengambilan Keputusan Karir Pada Siswa Kelas XII SMA Negeri 1 Kalasan, E-Journal Bimbingan dan Konseling, Volume 06 (01).

Stitt-Gohdes, W. (1997). Career Development.Columbus, Ohio: ERIC Clearinghouse on Adult, Career and Vocational Education.

Sugiyono. (2018). Metode Penelitian Kuantitatif Kualitatif Dan $R \& D$, Yogyakarta: Bandung: ALFABETA.

Susanto, Ahmad. (2018). Bimbingan dan Konseling Di Sekolah: Konsep, Teori, dan Aplikasinya. Jakarta: Prenadamedia Group.

Tim Penyusun Kamus Pusat Bahasa. (2003). Kamus Besar Bahasa Indonesia (Edisi Ketiga). Jakarta: Balai Pustaka. 